\title{
PENGARUH KINERJA KEUANGAN DAERAH TERHADAP BELANJA MODAL UNTUK PELAYANAN PUBLIK DALAM PERSPEKTIF TEORI KEAGENAN
}

(Studi Pada Kabupaten/Kota Se-Sumatera)

\author{
Riswan \\ Anthony Affandi \\ (Universitas Bandar Lampung) \\ Email: riswan@ubl.ac.id
}

\begin{abstract}
Fiscal capacity in the financial performance of the show, can be used as a tool to measure the success of carrying out local autonomy. The progress of the region one of which can be reviewed with good economic growth. The purpose of this study was to obtain empirical evidence on the influence of financial performance of the capital expenditure for public services at District / Municipal Se - Sumatra. Tests were conducted at 151 County / City of Se - Sumatra through quantitative analysis with simple regression . financial performance is measured by the ratio of the area of financial independence, financial effectiveness and efficiency ratios finances. While capital expenditures for public services is measured by the amount of capital for public service in the budget. The results showed that the financial performance of the positive effect on capital expenditures for public services at District / Municipal Se - Sumatra. Therefore, local governments should prioritize the financial performance of local governments to rise local capital expenditures.
\end{abstract}

Keywords : Financial Performance, Capital Expenditures for Public Service

\section{Latar Belakang}

Kebijakan pengelolaan keuangan daerah tidak terlepas dari kebijakan desentralisasi dan otonomi daerah yang menekankan pada prinsip money follows function sebagai konsekuensi dari hubungan keuangan antara pemerintah pusat dan pemerintah daerah. Pembaharuan subjek pengelolaan keuangan daerah yang ada dalam Undang-Undang No 32 tahun 2004 adalah ekonomis, efektifitas, dan efisiensi pengelolaan keuangan daerah baik dari sisi pendapatan maupun belanja.

Inti dari pembaharuan tersebut adalah untuk mempertajam esensi pengelolaan keuangan daerah dalam sistem penyelenggaraan pemerintahan daerah yang menyangkut penjabaran terhadap hak dan kewajiban daerah dalam pengelolaan keuangan publik. Hal ini akan mempengaruhi prinsip pengelolaan, mekanisme penyusunan, pelaksanaan dan penatausahaan, pengendalian dan pengawasan, serta pertanggungjawaban keuangan daerah (BPK, 2009).

Kinerja keuangan pemerintah daerah merupakan indikator keberhasilan suatu daerah dalam mengelola keuangan. Baik atau tidaknya kinerja keuangan pemerintah daerah dapat 
dilihat dari kemandirian daerah, efektivitas pemungutan PAD dan efisiensi belanja daerah (Halim, 2002). Kinerja keuangan pemerintah daerah yang baik akan berdampak langsung pada peningkatan pelayanan dan kesejahteraan masyarakatnya. Peningkatan pelayanan dan kesejahteraan masyarakat (publik) dapat diwujudkan oleh pemerintah daerah, jika pemerintah daerah dalam menggunakan sumber pendapatan daerah lebih banyak untuk belanja modal pelayanan publik. Karena belanja modal pelayanan publik bersentuhan langsung dengan kepentingan masyarakat, namun pada prakteknya pemerintah daerah mengalami kesulitan untuk meningkatkan belanja modal pelayanan publik karena adanya moral hazard.

Motivasi yang melandasi penelitian ini adalah pengalokasian dana untuk belanja modal yang bensentuhan langsung dengan kepentingan masyarakat oleh pemerintah daerah di Indonesia nilainya masih sedikit dibandingkan dengan total belanja daerah. Menurut Direktorat Jenderal Perimbangan Keuangan (2012) nilai belanja modal pemerintah daerah di Indonesia selama periode 2010-2012 tidak lebih dari 30\% dari total belanja daerahnya. Kecilnya nilai belanja modal pemerintah daerah memicu permasalahan tentang sejauhmana kinerja keuangan pemerintah daerah mempengaruhi pola belanja pemerintah daerah khususnya belanja modal untuk pelayanan publik (Halim dan Abdullah, 2003). Nilai belanja modal pemerintah daerah di Indonesia selama periode 2009-2012 dapat dilihat pada tabel berikut:

Tabel 1

Struktur Belanja Pemerintah Daerah di Indonesia Periode 2010-2012

\begin{tabular}{|l|l|l|l|l|l|l|}
\hline $\begin{array}{c}\text { Komponen Belanja } \\
\text { Daerah }\end{array}$ & $\begin{array}{c}\text { 2010 } \\
(\mathbf{R p})\end{array}$ & \multicolumn{1}{|c|}{$(\boldsymbol{\%})$} & $\begin{array}{c}\mathbf{2 0 1 1} \\
(\mathbf{R p})\end{array}$ & \multicolumn{1}{|c|}{$(\boldsymbol{\%})$} & $\begin{array}{c}\mathbf{2 0 1 2} \\
(\mathbf{R p})\end{array}$ & \multicolumn{1}{|c|}{$(\boldsymbol{\%})$} \\
\hline Belanja Pegawai & 198.562 & 46,52 & 229.801 & 46,33 & 261.153 & 42,33 \\
\hline Belanja Barang \& Jasa & 82.007 & 19,21 & 104.221 & 21,01 & 122.225 & 19,81 \\
\hline Belanja Modal & 96.179 & 22,53 & 113.523 & 22,88 & 137.438 & 22,28 \\
\hline Belanja Lain-lain & 50.110 & 11,74 & 48.449 & 9,77 & 96.155 & 15,58 \\
\hline Total Belanja Daerah & 426.858 & 100,00 & 495.994 & 100,00 & 616.971 & 100,00 \\
\hline
\end{tabular}

Sumber: DJPK-RI, 2013

Penelitian ini merupakan replikasi penelitian Ardhini (2011) yang menguji pengaruh rasio keuangan pemerintah daerah terhadap belanja modal pemerintah daerah pada Pemerintah Kabupaten/Kota di Jawa Tengah. Hasil analisis menunjukkan bahwa tingkat kemandirian keuangan daerah tidak berpengaruh signifikan negatif terhadap belanja modal, tingkat efektivitas berpengaruh positif signifikan terhadap belanja modal, efisiensi tidak berpengaruh signifikan terhadap belanja modal, SiLPA berpengaruh positif signifikan 
terhadap belanja modal, belanja modal berpengaruh negatif signifikan terhadap pertumbuhan ekonomi.

Perbedaan penelitian ini dengan penelitian Moral hazard pemerintah daerah dipertanyakan dalam hal penggunaan penerimaan daerah khususnya PAD. PAD yang tinggi mencerminkan keuangan daerah yang maju, sehingga pengalokasian untuk belanja modal juga dipertanyakan. Daerah yang maju tidak serta merta untuk mengalokasikan belanja modal yang besar demi kepentingan masyarakatnya (Handayani, 2011). Pengalokasian belanja modal menjadi permasalahan krusial di pemerintah daerah mengingat sejauh mana pentingnya diadakan pendanaan untuk belanja modal.

\section{Tinjauan Pustaka dan Hipotesis}

\subsection{Teori Keagenan}

Konsep agency teory menurut Anthony dan Govindarajan (1995) dan Ma'ruf (2006) adalah hubungan atau kontak antara principal dan agent. Principal mempekerjakan agent untuk melakukan tugas untuk kepentingan principal, termasuk pendelegasian otorisasi pengambilan keputusan dari principal kepada agent. Perspektif hubungan keagenan merupakan dasar yang digunakan untuk memahami hubungan antara manajer dan pemegang saham. Jensen dan Meckling (1976) menyatakan bahwa hubungan keagenan adalah sebuah kontrak antara manajer (agent) dengan pemegang saham (principal). Hubugan kegenan tersebut terkadang menimbulkan masalah antara manajer dan pemegang saham.

\section{Hubungan Keagenan dalam Penyusunan Anggaran Daerah}

Konflik yang terjadi karena manusia adalah makhluk ekonomi yang mempunyai sifat dasar mementingkan kepentingan diri sendiri. Pemegang saham dan manajer memiliki tujuan yang berbeda dan masing-masing menginginkan tujuan mereka terpenuhi. Akibat yang terjadi adalah munculnya konflik kepentingan. Pemegang saham menginginkan pengembalian yang lebih besar dan secepat-cepatnya atas investasi yang mereka tanamkan sedangkan manajer menginginkan kepentingannya diakomodasi dengan pemberian kompensasi atau insentif yang sebesar-besarnya atas kinerjanya dalam menjalankan organisasi. 


\section{Hubungan Keagenan dalam Penyusunan Anggaran Daerah}

Konflik kepentingan antara prinsipal dan agen memunculkan permasalahan keagenan seperti tidak adanya kesinkronan dalam hal utilitas. Sebagai agent, manajer secara moral bertanggung jawab untuk mengoptimalkan keuntungan para pemilik (principal), namun disisi yang lain manajer juga mempunyai kepentingan memaksimalkan kesejahteraan mereka. Sehingga ada kemungkinan besar agent tidak selalu bertindak demi kepentingan terbaik principal. (Jensen dan Meckling, 1976; Halim dan Abdullah, 2009).

Menurut Halim dan Abdullah (2009) teori keagenan dapat diterapkan dalam organisasi publik. Ia menyatakan bahwa negara demokrasi modern didasarkan pada serangkaian hubungan prinsipal-agen dan hubungan prinsipal agen merupakan suatu pendekatan yang sangat penting untuk menganalisis komitmen-komitmen kebijakan publik. Menurut Halim dan Abdullah (2009) model keagenan yang sederhana mengasumsikan dua pilihan dalam kontrak: (1) behavior-based, yakni prinsipal harus memonitor perilaku agen dan (2) outcomebased, yakni adanya insentif untuk memotivasi agen untuk mencapai kepentingan prinsipal. Para teoretisi berpegang pada proposisi bahwa agents behave opportunistically toward principals. Oportunisme bermakna bahwa ketika terjalin kerjasama antara prinsipal dan agen, kerugian prinsipal karena agen mengutamakan kepentingannya (agent self-interest) kemungkinan besar akan terjadi.

Menurut Halim dan Abdullah (2009) di pemerintahan terdapat suatu keterkaitan dalam kesepakatan-kesepakatan principal-agent yang dapat ditelusuri melalui proses anggaran: pemilih-legislatur, legislatur-pemerintah, menteri keuangan-pengguna anggaran, perdana menteri-birokrat, dan pejabat-pemberi pelayanan. Hal yang sama dikemukakan juga oleh Halim dan Abdullah (2009) yang melihat hubungan keagenan sebagai hubungan pendelegasian (chains of delegation), yakni pendelegasian dari masyarakat kepada wakilnya di parlemen, dari parlemen kepada pemerintah, dari pemerintah sebagai satu kesatuan kepada seorang menteri, dan dari pemerintah kepada birokrasi. Hubungan tersebut tidaklah selalu mencerminkan hirarki, tetapi dapat saja berupa hubungan pendelegasian.

\section{Hubungan Keagenan Antara Eksekutif dan Legislatif}

Dalam hubungan keagenan di pemerintahan antara eksekutif dan legislatif, eksekutif adalah agen dan legislatif adalah prinsipal (Halim dan Abdullah, 2009). Seperti dikemukakan sebelumnya, di antara prinsipal dan agen senantiasa terjadi masalah keagenan. Oleh karena 
itu, persoalan yang sering timbul di antara eksekutif dan legislatif juga merupakan persoalan keagenan.

Halim dan Abdullah (2009) menyatakan bahwa masalah yang dihadapi legislatur dapat diartikan sebagai fenomena yang disebut agency problems. Masalah keagenan paling tidak melibatkan dua pihak, yakni prinsipal, yang memiliki otoritas untuk melakukan tindakantindakan, dan agen, yang menerima pendelegasian otoritas dari prinsipal. Dalam konteks pembuatan kebijakan oleh legislatif, legislatur adalah prinsipal yang mendelegasikan kewenangan kepada agen seperti pemerintah atau panitia di legislatif untuk membuat kebijakan baru. Hubungan keagenan di sini terjadi setelah agen membuat usulan kebijakan dan berakhir setelah usulan tersebut diterima atau ditolak.

Halim dan Abdullah (2009) juga menyebut hubungan eksekutif atau birokrasi dengan legislatif atau kongres dengan nama self-interest model. Dalam hal ini, legislators ingin dipilih kembali, birokrat ingin memaksimumkan anggarannya, dan konstituen ingin memaksimumkan utilitasnya. Agar terpilih kembali, legislators mencari program dan projects yang membuatnya populer di mata konstituen. Birokrat mengusulkan programprogram baru karena ingin agency-nya berkembang dan konstituen percaya bahwa mereka menerima benefits dari pemerintah tanpa harus membayar biayanya secara penuh. Sebagai Prinsipal, legislatif dapat juga berperilaku moral hazard atau dalam merealisasikan selfinterestnya seperti berlaku korup (corrupt principals). Adanya discretionary power di salah satu pihak akan menimbulkan pelanggaran atas kontrak keagenan, seperti terjadinya perilaku rent-seeking dan korupsi.

\section{Hubungan Keagenan dalam Pemanfaatan Anggaran Daerah di Indonesia}

Anggaran daerah merupakan rencana keuangan yang menjadi dasar dalam pelaksanaan pelayanan publik. Di Indonesia dokumen anggaran daerah disebut anggaran pendapatan dan belanja daerah (APBD), baik untuk provinsi maupun kabupaten dan kota. Proses penyusunan anggaran pasca UU 22/1999 (dan UU 32/2004) melibatkan dua pihak: eksekutif dan legislatif, masing-masing melalui sebuah tim atau panitia anggaran.

\section{Masalah Keagenan di Eksekutif}

Eksekutif memiliki keunggulan dalam hal penguasaan informasi dibanding legislatif (asimetri informasi). Keunggulan ini bersumber dari kondisi faktual bahwa eksekutif adalah pelaksana semua fungsi pemerintah daerah dan berhubungan langsung dengan masyarakat 
dalam waktu sangat lama. Eksekutif memiliki pemahaman yang baik tentang birokrasi dan administrasi serta peraturan perundang-undangan yang mendasari seluruh aspek pemerintahan. Oleh karena itu, anggaran untuk pelaksanaan pelayanan publik diusulkan untuk dialokasikan dengan didasarkan pada asumsi-asumsi sehingga memudahkan eksekutif memberikan pelayanan dengan baik.

Eksekutif akan memiliki kecenderungan mengusulkan anggaran belanja yang lebih besar dari yang aktual terjadi saat ini (asas maksimal). Sebaliknya untuk anggaran pendapatan, eksekutif cenderung mengusulkan target yang lebih rendah (asas minimal) agar ketika realisasi dilaksanakan, target tersebut lebih mudah dicapai. Usulan anggaran yang mengandung slack seperti ini merupakan gambaran adanya asimetri informasi antara eksekutif dan legislatif. Slack tersebut terjadi karena agen (eksekutif) menginginkan posisi yang relatif aman dan nyaman dalam melaksanakan tugas dan fungsinya (Halim, 2009).

\subsection{Anggaran Pendapatan dan Belanja Daerah (APBD)}

Undang-Undang No. 32/2004 tentang Pemerintahan Daerah dan Undang-Undang No. 33/2004 tentang Perimbangan Keuangan Pusat dan Daerah menyebutkan bahwa Anggaran Pendapatan dan Belanja Daerah (APBD) adalah rencana keuangan tahunan pemerintah daerah yang dibahas dan disetujui bersama oleh pemerintah daerah dan DPRD, dan ditetapkan dengan peraturan daerah.

\section{Belanja Daerah}

Belanja daerah adalah semua pengeluaran kas daerah yang mengurangi ekuitas dana lancar dalan periode tahun anggaran bersangkutan yang tidak akan diperoleh pembayarannya kembali oleh pemerintah yang meliputi belanja operasional dan belanja modal serta belanja lain-lain/tidak tersangka (SAP No.2). Belanja menurut kelompok belanja:

1. Belanja Tidak Langsung merupakan belanja yang dianggarkan tidak terkait secara langsung dengan pelaksanaan program dan kegiatan, yang terdiri atas: belanja pegawai, bunga, subsidi, hibah, bantuan sosial, belanja bagi hasil, bantuan keuangan, dan belanja tidak terduga

2. Belanja langsung merupakan belanja yang dianggarkan terkait secara langsung dengan pelaksanaan program dan kegiatan, yang terdiri atas: belanja pegawai, belanja barang dan jasa; dan belanja modal. 
Belanja modal digunakan untuk pengeluaran yang dilakukan dalam rangka pembelian/ pengadaan atau pembangunan aset tetap berwujud yang mempunyai nilai manfaat lebih dari 12 (duabelas) bulan untuk digunakan dalam kegiatan pemerintahan, seperti dalam bentuk tanah, peralatan dan mesin, gedung dan bangunan, jalan, irigasi dan jaringan, dan aset tetap lainnya.

\section{Pembiayaan}

Menurut Peraturan Menteri Dalam Negeri No. 59 tahun 2007 pasal 1 ayat 54, Pembiayaan Daerah adalah semua penerimaan yang perlu dibayar kembali dan/ atau pengeluaran yang akan diterima kembali, baik pada tahun anggaran yang bersangkutan maupun pada tahun-tahun anggaran berikutnya.

\section{Kinerja Keuangan Pemerintah Daerah}

Kinerja keuangan pemerintah daerah adalah kemampuan suatu daerah untuk menggali dan mengelola sumber-sumber keuangan asli daerah dalam memenuhi kebutuhannya guna mendukung berjalannya sistem pemerintahan, pelayanan kepada masyarakat dan pembangunan daerahnya dengan tidak tergantung sepenuhnya kepada pemerintah pusat dan mempunyai keleluasaan di dalam menggunakan dana-dana untuk kepentingan masyarakat daerah dalam batas-batas yang ditentukan peraturan perundang-undangan (Syamsi,1986: 199).

Organisasi sektor publik (Pemerintah) merupakan organisasi yang bertujuan memberikan pelayanan publik kepada masyarakat dengan sebaik-baiknya, misalnya dalam bidang pendidikan, kesehatan, keamanan, penegakan hukum, transportasi dan sebagainya. Pelayanan publik diberikan karena masyarakat merupakan salah satu stakeholder organisasi sektor publik. Sehingga pemerintah tidak hanya menyampaikan laporan pertanggungjawaban kepada pemerintah pusat saja, tetapi juga kepada masyarakat luas.

\section{Rasio Kemandirian Keuangan Daerah}

Rasio kemandirian keuangan daerah menunjukkan kemampuan pemerintah daerah dalam membiayai sendiri kegiatan pemerintahan, pembangunan, dan pelayanan kepada masyarakat yang telah membayar pajak dan retribusi, yang dapat diformulasikan sebagai berikut (Halim, 2002:128): 


$$
\text { Rasio Kemandirian } \quad \boldsymbol{i}=\frac{P A D i}{\text { Total Pendapatan Daerah } i} \times 100 \%
$$

Ket $: i=$ Seluruh Kabupaten/Kota se-Sumatera

Rasio kemandirian menggambarkan ketergantungan daerah terhadap sumber dana eksternal. Semakin tinggi rasio kemandirian mengandung arti bahwa tingkat ketergantungan daerah terhadap bantuan pihak eksternal (terutama pemerintah pusat dan provinsi) semakin rendah, dan dengan demikian pula sebaliknya. Rasio kemandirian juga menggambarkan tingkat partisipasi masyarakat dalam pembangunan daerah. Semakin tinggi masyarakat membayar pajak dan retribusi daerah akan menggambarkan tingkat kesejahteraan masyarakat yang semakin tinggi (Halim, $2002: 233$ ).

\section{Rasio Efektifitas Keuangan Daerah}

Rasio efektifitas keuangan daerah menggambarkan kemampuan pemerintah daerah dalam merealisasikan PAD yang direncanakan dibandingkan dengan target PAD yang ditetapkan. Rumusan rasio efektifitas yaitu (Halim, 2002:130) :

$$
\text { Rasio Efektivitas } i=\frac{\text { Realisasi PAD } i}{\text { Target Penerimaan PAD } i} \times 100 \%
$$

Ket $: i=$ Seluruh Kabupaten/Kota se-Sumatera

\section{Rasio Efisiensi Keuangan Pemerintah Daerah}

Rasio efisiensi keuangan daerah adalah rasio yang menggambarkan perbandingan antara output dan input atau realisasi pengeluaran daerah dengan realisasi penerimaan daerah. Semakin kecil rasio ini, maka semakin efisien, begitu pula sebaliknya. Pada sektor pelayanan masyarakat adalah suatu kegiatan yang dilakukan dengan baik dan pengorbanan seminimal mungkin. Suatu kegiatan dikatakan telah dikerjakan secara efisien jika pelaksanaan pekerjaan tersebut telah mencapai hasil (output) dengan biaya (input) yang terendah atau dengan biaya minimal diperoleh hasil yang diinginkan. Rasio efisiensi diukur dengan (Halim, 2002:131):

$$
\text { Rasio Efisiensi } i=\frac{\text { Realisasi Belanja Daerah } i}{\text { Realisasi Pendapatan Daerah } i} \times 100 \%
$$

Ket $: i=$ Seluruh Kabupaten/Kota se-Sumatera 


\section{Belanja Modal untuk Pelayanan Publik}

Belanja modal jenis pelayanan publik adalah belanja yang digunakan untuk membiayai kegiatan investasi (menambah aset) yang ditujukan untuk peningkatan sarana dan prasarana publik yang hasilnya dapat digunakan langsung oleh masyarakat. Belanja modal jenis ini terdiri atas belanja tanah, belanja modal jalan dan jembatan, belanja modal bangunan air (irigasi), belanja modal instalasi, belanja modal jaringan, belanja modal bangunan gedung untuk kegiatan kemasyarakatan, belanja modal monumen, belanja modal alat-alat angkutan, alat-alat bengkel, alat-alat alat-alat kedokteran, alat-alat laboratorium, belanja modal buku/perpustakaan, barang bercorak kesenian dan budaya, belanja modal hewan ternak serta tanaman, belanja modal alat-alat persenjataan/keamanan. Rasio belanja modal pemerintah terhadap total belanja digunakan untuk mengukur seberapa jauh/besar kebijakan pemerintah dalam penganggaran yang berorientasi kepada manfaat jangka panjang atau investasi.

\subsection{Kerangka Pemikiran Teoritis}

Berdasarkan kajian teoritis, tinjauan penelitian terdahulu dan permasalahan yang telah dikemukakan maka secara sistematik kerangka pemikiran teoritis dapat digambarkan sebagai berikut:

\section{Gambar 1}

\section{Kerangka Pemikiran Teoritis}

\section{$\underline{\text { Kinerja Keuangan Daerah }}$}

-Rasio Kemandirian Keuangan Daerah -Rasio Efektifitas Keuangan Daerah -Rasio Efisiensi Keuangan Daerah Sumber:Halim, 2002
Belanja Modal untuk Pelayanan Publik (Y)

Belanja Tanah, Belanja Jalan \& Jembatan, irigasi, dan Aset Tetap lainnya

Sumber:Permendagri No. 13/ 2006

\subsection{Hipotesis}

Menurut Halim (2007) kinerja keuangan pemerintah dapat diukur melalui rasio keuangan. Beberapa rasio keuangan yang umum dipakai untuk mengukur kinerja keuangan pemerintah daerah adalah rasio kemandirian, rasio efektifitas, dan rasio efisiensi. Rasio kemandirian daerah menunjukkan kemampuan pemerintah daerah dalam membiayai sendiri kegiatan pemerintahan, pembangunan, dan pelayanan kepada masyarakat. Semakin tinggi rasio ini berarti tingkat ketergantungan daerah terhadap bantuan pihak ekstern (terutama pemerintah pusat dan provinsi) semakin rendah, demikian pula sebaliknya. 
Dalam konteks efisiensi dan efektivitas anggaran, maka pemanfaatan anggaran secara sederhana dapat dikatakan bertujuan untuk memberikan efek kepada peningkatan kualitas layanan masyarakat dan kesejahteraan masyarakat secara maksimal yang menjadi kepentingan masyarakat pada umumnya (Chalid, 2005). Dari penjelasan di atas, maka hipotesis dalam penelitian ini adalah:

Ha : Kinerja keuangan daerah berupa kemandirian keuangan, efektivitas keuangan dan efisiensi keuangan berpengaruh terhadap belanja modal untuk pelayanan publik.

\section{Metode Penelitian}

\subsection{Populasi dan Teknik Pengambilan Sampel}

Populasi dalam penelitian ini adalah seluruh Pemerintah Kabupaten /Kota se-Sumatera yang berjumlah 151 Pemerintah Kabupaten /Kota. Sampel merupakan sebagian dari populasi yang karakteristiknya dianggap dapat mewakili populasi (Sekaran, 2006). Tehnik penentuan sampel dalam penelitian ini menggunakan purposive sampling. Sekaran (2006) menjelaskan bahwa purposive sampling adalah pengambilan sampel yang didasarkan pada kreteria tertentu untuk mencapai tujuan penelitian. Adapun kreteria penarikan sampel dalam penelitian ini adalah:

1) Kabupaten/Kota yang menyampaikan Laporan Realisasi APBD tahun 2011 dan telah diaudit oleh BPK-RI.

2) Laporan Realisasi APBD yang dipublikasikan bisa diakses dan memiliki informasi yang lengkap untuk diolah.

\subsection{Jenis dan Sumber Data}

Data yang dianalisis dalam penelitian ini adalah data kuantitatif berupa Laporan Realisasi APBD tahun 2011. Laporan Realisasi APBD tahun 2011 bersumber dari data sekunder, yakni data yang bersumber dari www.djpk.depkeu.go.id

\subsection{Variabel Penelitian}

Variabel dalam penelitian ini terdiri atas 2 (dua) jenis, yakni variabel independen (variabel bebas) dan variabel dependen (variabel terikat). Variabel independen pada penelitian ini adalah kinerja keuangan pemerintah daerah. Sedangkan variabel dependen adalah belanja modal untuk pelayanan publik. 


\subsection{Definisi Operasional dan Pengukuran Variabel}

Definisi operasional dimaksudkan untuk menjabarkan variabel ke dalam suatu penelitian yang berupa indikator yang lebih terperinci, sehingga akan mempermudah pengukurannya. Pengukuran variabel secara operasional sebagai berikut :

\section{Kinerja Keuangan Pemerintah Daerah}

Kinerja keuangan pemerintah daerah adalah kemampuan suatu daerah untuk menggali dan mengelola sumber-sumber keuangan asli daerah dalam memenuhi kebutuhannya guna mendukung berjalannya sistem pemerintahan, pelayanan kepada masyarakat dan pembangunan daerahnya dengan tidak tergantung sepenuhnya kepada pemerintah pusat dan mempunyai keleluasaan di dalam menggunakan dana-dana untuk kepentingan masyarakat daerah dalam batas-batas yang ditentukan peraturan perundang-undangan. Adapun indikator pengukuran kinerja keuangan pemerintah daerah mengacu pada (Halim, 2002) yakni: rasio kemandirian keuangan daerah, rasio efektifitas keuangan daerah, dan rasio efisiensi keuangan daerah

\section{Rasio Kemandirian Daerah}

Kemandirian daerah yang dimaksud dalam penelitian ini adalah kemampuan pendapatan daerah dalam membiayai pengeluaran pemerintah daerah. Sehingga ketergantungan kepada pemerintah pusat mempunyai proporsi yang lebih kecil, dan pendapatan asli daerah harus menjadi bagian yang terbesar dalam memobilisasi penyelenggaraan pemerintahan. Rumusan rasio kemandirian daerah yaitu :

$$
\begin{aligned}
& \text { Rasio Kemandirian } i=\frac{P A D i}{\text { Total Pendapatan Daerah } i} \times 100 \% \\
& \text { Ket }: i=\text { Seluruh Kabupaten/Kota se-Sumatera }
\end{aligned}
$$

Adapun kreteria penilaian kemandirian keuangan pemerintah daerah sebagai berikut :

\section{Tabel 2}

\section{Kreteria Penilaian Kemandirian Keuangan}

\begin{tabular}{|c|c|c|}
\hline Kemandirian Keuangan (\%) & Kreteria & Pola Hubungan \\
\hline $0-25$ & Rendah Sekali & Instruktif \\
\hline $25-50$ & Rendah & Konsultatif \\
\hline $50-75$ & Sedang & Partisipatif \\
\hline $75-100$ & Tinggi & Delegatif \\
\hline
\end{tabular}

Sumber : Keputusan Mendagri No. 690.900.327 Tahun 1996 (Halim, 2002) 


\section{Rasio Efektivitas Keuangan Daerah}

Efektivitas keuangan daerah menggambarkan kemampuan pemda dalam merealisasikan PAD yang direncanakan dibandingkan dengan target PAD yang ditetapkan. Rumusan rasio efektivitas yaitu :

$$
\text { Rasio Efektivitas } i=\frac{\text { Realisasi PAD } i}{\text { Target Penerimaan PAD } i} \times 100 \%
$$

Ket $: i=$ Seluruh Kabupaten/Kota se-Sumatera

Adapun kreteria penilaian efektivitas keuangan pemerintah daerah sebagai berikut :

Tabel 3

\section{Kreteria Penilaian Efektivitas Keuangan}

\begin{tabular}{|c|c|}
\hline \% Efektifitas Keuangan & Kreteria \\
\hline Diatas 100 & Sangat Efektif \\
\hline $90-100$ & Efektif \\
\hline $80-90$ & Cukup Efektif \\
\hline $60-80$ & Kurang Efektif \\
\hline Dibawah 60 & Tidak Efektif \\
\hline
\end{tabular}

Sumber: Keputusan Mendagri No. 690.900.327

Tahun 1996 (Halim, 2002)

\section{Rasio Efisiensi Keuangan Daerah}

Rasio efisiensi adalah rasio yang menggambarkan perbandingan antara output dan input atau realisasi pengeluaran dengan realisasi penerimaan daerah. Semakin kecil rasio ini, maka semakin efisien, begitu pula sebaliknya. Dalam hal ini dengan mengasumsikan bahwa pengeluaran yang dibelanjakan sesuai dengan peruntukkannya dan memenuhi dari apa yang direncanakan. Pada sektor pelayanan masyarakat adalah suatu kegiatan yang dilakukan dengan baik dan pengorbanan seminimal mungkin. Suatu kegiatan dikatakan telah dikerjakan secara efisien jika pelaksanaan pekerjaan tersebut telah mencapai hasil (output) dengan biaya (input) yang terendah atau dengan biaya minimal diperoleh hasil yang diinginkan. Rasio efisiensi diukur dengan:

$$
\text { Rasio Efisiensi } i=\frac{\text { Realisasi Belanja Daerah } i}{\text { Realisasi Pendapatan Daerah } i} \times 100 \%
$$

Ket $: i=$ Seluruh Kabupaten/Kota se-Sumatera

Adapun kreteria penilaian efisiensi keuangan pemerintah daerah sebagai berikut : 
Tabel 4

Kreteria Penilaian Efisiensi Keuangan

\begin{tabular}{|c|c|}
\hline \% Efisiensi Keuangan & Kreteria \\
\hline Diatas 100 & Tidak Efisien \\
\hline $90-100$ & Kurang Efisien \\
\hline $80-90$ & Cukup Efisien \\
\hline $60-80$ & Efisien \\
\hline Dibawah 60 & Sangat Efisien \\
\hline
\end{tabular}

Sumber : Keputusan Mendagri No. 690.900.327 Tahun 1996 (Halim, 2002)

\section{Belanja Modal untuk Pelayanan Publik}

Belanja modal jenis pelayanan publik adalah belanja yang digunakan untuk membiayai kegiatan investasi (menambah aset) yang ditujukan untuk peningkatan sarana dan prasarana publik yang hasilnya dapat digunakan langsung oleh masyarakat. Belanja modal jenis ini terdiri atas belanja tanah, belanja modal jalan dan jembatan, belanja modal bangunan air (irigasi), belanja modal instalasi, belanja modal jaringan, belanja aset tetap lainnya untuk kegiatan kemasyarakatan (Permendagri No. 13 tahun 2006).

\subsection{Teknik Analisis}

Penelitian ini menggunakan analisis kualitatif dan kuantitatif. Analisis kualitatif dilakukan dengan menggunakan statistik deskriptif. Sedangkan analisis kuantitatif lebih fokus pada tujuan untuk generalisasi dengan melakukan pengujian statistik (Sekaran, 2006).

\section{Analisis Kualitatif}

Analisis kualitatif dilakukan dengan menggunakan statistik deskriptif. Penyajian statistik deskriptif bertujuan untuk memudahkan memberikan gambaran atau deskripsi suatu data yang dilihat dari nilai rata-rata, standar deviasi, maksimum, dan minimum.

\section{Analisis Kuantitatif}

Analisis kuantitatif pada penelitian ini dilakukan dengan menggunakan: regresi linier sederhana, pengujian hipotesis, dan koefisien determinasi.

\section{Regresi Linier Sederhana}

Regresi linier sederhana digunakan untuk melihat pengaruh kinerja keuangan pemerintah daerah terhadap belanja modal untuk pelayanan publik. Adapun rumus persamaan regresi sebagai berikut: 


$$
\hat{\mathbf{Y}}=\mathbf{a}+\mathbf{b X}+\mathbf{e t}
$$

Keterangan:

$$
\begin{array}{ll}
\hat{\mathrm{Y}} & : \text { Belanja Modal untuk Pelayanan Publik } \\
\mathrm{X} & : \text { Kinerja Keuangan Pemerintah Daerah } \\
\mathrm{a} & : \text { Konstanta } \\
\mathrm{b}_{1}, \mathrm{~b}_{2}, \mathrm{~b}_{3}: & \text { Parameter Penduga } \\
\text { et } \quad: \text { Error Term }
\end{array}
$$

\section{Pengujian Hipotesis}

Untuk membuktikan hasil penelitian, maka perlu dilakukan pengujian hipotesis. Pengujian hipotesis dilakukan melalui uji t_statistik dengan tingkat kepercayaan $90 \%$ atau $(\alpha=0,10)$. Adapun langkah-langkah pengujian hipotesis sebagai berikut :

1) Menentukan Hipotesis

Ho = Kinerja keuangan pemerintah daerah tidak berpengaruh terhadap belanja modal pelayanan publik.

$\mathrm{Ha}=$ Kinerja keuangan pemerintah daerah berpengaruh terhadap belanja modal pelayanan publik.

2) Hipotesis Statistik

Ho: $\beta=0 \quad$ Kinerja keuangan pemerintah daerah tidak berpengaruh terhadap belanja modal pelayanan publik.

Ha: $\beta \neq 0 \quad$ Kinerja keuangan pemerintah daerah berpengaruh terhadap belanja modal pelayanan publik.

3) Kesimpulan

a) Jika $p_{\text {_value }}<\alpha=0,10$, maka $\mathrm{H}_{\mathrm{o}}$ ditolak, $\mathrm{H}_{\mathrm{a}}$ diterima. Artinya kinerja keuangan pemerintah daerah berpengaruh terhadap belanja modal pelayanan publik.

b) Jika p_value $>\alpha=0,10$, maka $\mathrm{H}_{\mathrm{o}}$ diterima, $\mathrm{H}_{\mathrm{a}}$ ditolak. Artinya kinerja keuangan pemerintah daerah tidak berpengaruh terhadap belanja modal pelayanan publik.

\section{Hasil dan Pembahasan}

\subsection{Statistik Deskriptif}

Statistik deskriptif pada penelitian ini ditujukan untuk menggambarkan kinerja keuangan dan belanja modal untuk pelayanan publik pada pemerintah Kabupaten/Kota seSumatera melalui nilai mean, nilai minimum, nilai maksimum, dan nilai sum sehingga mudah 
dipahami. Rasio keuangan daerah yang digunakan pada penelitian ini adalah rasio kemandirian keuangan, rasio efektifitas keuangan, dan rasio efisiensi keuangan. Rasio kemandirian keuangan menunjukkan kemampuan pemerintah daerah dalam membiayai sendiri kegiatan pemerintahan, pembangunan dan pelayanan kepada masyarakat yang telah membayar pajak dan retribusi sebagai sumber pendapatan yang diperlukan daerah.

Rasio efektifitas keuangan menggambarkan kemampuan pemerintah daerah dalam merealisasikan PAD yang direncanakan dibandingkan dengan target PAD yang ditetapkan. Sedangkan rasio efisiensi keuangan menggambarkan kemampuan pemerintah daerah dalam membelanjakan dana yang diperoleh, baik dari PAD maupun dari sumber lainnya. Adapun hasil uji statistik deskriptif atas kinerja keuangan dan belanja modal untuk pelayanan publik pemerintah Kabupaten/Kota se-Sumatera tahun anggaran 2011 dapat disajikan pada tabel berikut ini:

Tabel 5

Hasil Statistik Deskriptif

\begin{tabular}{|l|l|l|l|l|l|}
\hline Keterangan & $\mathrm{n}$ & Mean & Min & Max & Sum \\
\hline Kemandirian Keuangan & 151 & 5,52 & 0,98 & 36,22 & \\
\hline -Sangat Rendah & 148 & & & & \\
\hline -Rendah & 3 & & & & \\
\hline -Sedang & 0 & & & & \\
\hline -Tinggi & 0 & & & & \\
\hline Efektivitas Keuangan & 151 & 102,32 & 23,32 & 262,58 & \\
\hline -Sangat Efektif & 80 & & & & \\
\hline -Efektif & 26 & & & & \\
\hline -Cukup Efektif & 15 & & & & \\
\hline -Kurang Efektif & 19 & & & & \\
\hline -Tidak Efektif & 11 & & & & \\
\hline Efisiensi Keuangan & 151 & 96,13 & 73,77 & 116,30 & \\
\hline -Tidak Efisien & 35 & & & & \\
\hline -Kurang Efisien & 94 & & & & \\
\hline -Cukup Efisien & 22 & & & & \\
\hline -Efisien & 0 & & & & \\
\hline -Sangat Efisien & 0 & & & & \\
\hline Belanja Modal & 151 & 158,47 & 45,50 & 885,87 & 23,93 \\
\hline$>100$ Milyar & 114 & & & & \\
\hline$<100$ Milyar & 37 & & & & \\
\hline
\end{tabular}

Sumber: Data Diolah, 2014

Tabel diatas menunjukkan bahwa nilai mean kemandirian keuangan 151 pemerintah Kabupaten/Kota yang ada di pulau Sumatera sebesar 5,52 dan masuk dalam kreteria "rendah 
sekali” dengan pola hubungan instruktif. Hal ini menunjukkan bahwa secara rata-rata pemerintah kabupaten/kota yang ada di pulau Sumatera tidak mampu melaksanakan otonomi daerah, karena nilai PAD yang merupakan sumber pendapatan intern suatu daerah sangat kecil dibandingkan dengan pendapatan ekternnya. Dari 151 pemerintah daerah se-pulau Sumatera, tidak ada satupun tingkat kemandiriannya yang baik, yakni dibawah $25 \%$.

Nilai mean efektivitas keuangan 151 pemerintah Kabupaten/Kota yang ada di pulau Sumatera sebesar 102,32 dan masuk dalam kreteria "sangat efektif". Hal ini menunjukkan bahwa secara rata-rata pemerintah kabupaten/kota yang ada di pulau Sumatera sangat efektif dalam merealisasikan PAD yang telah dianggarkan. Selain itu secara rata-rata pemerintah kabupaten/kota yang ada di pulau Sumatera juga dapat melampaui target PAD yang telah dianggarkan. Tingkat efektivitas keuangan yang tertinggi adalah Kabupaten Nias Utara Propinsi Sumatera Utara sebesar 262,58\%, sedangkan tingkat efektivitas keuangan terendah adalah Kabupaten Aceh Timur Propinsi Nanggro Aceh Darussalam sebesar 23,32\%. Dari 151 pemerintah Kabupaten/Kota yang ada di pulau Sumatera, 80 kabupaten/kota memperoleh predikat "sangat efektif", 26 kabupaten/kota memperoleh predikat "efektif", 15 kabupaten/kota memperoleh predikat “cukup efektif", 19 kabupaten/kota memperoleh predikat "kurang efektif" dan 11 kabupaten/kota memperoleh predikat "tidak efektif” (secara lengkap dapat dilihat pada lampiran 1).

Nilai mean efisiensi keuangan 151 pemerintah Kabupaten/Kota yang ada di pulau Sumatera sebesar 96,13 dan masuk dalam kreteria "kurang efisien". Hal ini menunjukkan bahwa secara rata-rata pemerintah kabupaten/kota yang ada di pulau Sumatera kurang efisien dalam membelanjakan pendapatannya. Dari 151 pemerintah daerah se-pulau Sumatera, 35 kabupaten/kota memperoleh predikat "tidak efisien”, 94 kabupaten/kota memperoleh predikat "kurang efisien" dan 22 kabupaten/kota memperoleh predikat "cukup efisien" (secara lengkap dapat dilihat pada lampiran 1).

\subsection{Regresi Linier Sederhana}

Penelitian ini bertujuan untuk memberikan bukti empiris pengaruh kinerja keuangan daerah terhadap belanja modal untuk pelayanan publik pada pemerintah Kabupaten/Kota seSumatera. Berdasarkan hasil pengolahan data (lampiran 2), maka persamaan regresi untuk pengaruh kinerja keuangan daerah terhadap belanja modal pelayanan publik adalah sebagai berikut:

$$
\mathrm{BM}=3.932+1.753 \mathrm{KK}
$$


Berdasarkan persamaan regresi tersebut dapat dijelaskan bahwa kinerja keuangan memiliki pengaruh positif terhadap belanja modal untuk pelayanan publik yang dapat dilihat pada nilai koefisien regresi (beta) untuk kinerja keuangan sebesar +1.753 pada konstanta 3.932. Hal ini dapat diartikan bahwa setiap kenaikan terhadap kinerja keuangan pemerintah Kabupaten/Kota se-Sumatera sebesar 1\%, maka belanja modal untuk pelayanan publik pada pemerintah Kabupaten/Kota se-Sumatera akan meningkat (naik) sebesar Rp. 1,75 milyar pada konstanta sebesar Rp. 3,93 milyar, dan berlaku sebaliknya.

\subsection{Pengujian Hipotesis}

Pengujian hipotesis dilakukan untuk menjawab hipotesis penelitian. Untuk menguji apakah hipotesis yang diajukan diterima atau ditolak, maka dilakukan pengujian hipotesis dengan menggunakan uji t_statistik pada tingkat kepercayaan $90 \%$ atau $(\alpha=0,10)$.

Adapun kriteria atau ketentuan penerimaan dan penolakan pengujian hipotesis dengan uji t_statistik sebagai berikut :

Jika p_value $<\alpha=0,10$, maka $\mathrm{H}_{\mathrm{o}}$ ditolak, $\mathrm{H}_{\mathrm{a}}$ diterima.

Jika p_value $>\alpha=0,10$, maka $\mathrm{H}_{\mathrm{o}}$ diterima, $\mathrm{H}_{\mathrm{a}}$ ditolak.

Berdasarkan hasil pengolahan data diperoleh nilai p_value untuk pengujian hipotesis pengaruh kinerja keuangan daerah terhadap belanja modal untuk pelayanan publik adalah sebagai berikut:

\section{Tabel 6}

\section{Hasil Pengujian Hipotesis}

\begin{tabular}{|c|l|c|l|l|}
\hline Ha & \multicolumn{1}{|c|}{ Hipotesis } & Beta & P_value & \multicolumn{1}{|c|}{ Kesimpulan } \\
\hline $\begin{array}{l}\text { Kinerja keuangan daerah berpengaruh } \\
\text { positif terhadap belanja modal untuk } \\
\text { pelayanan publik. }\end{array}$ & 1.753 & 0,060 & $\begin{array}{l}\text { Hipotesis } \\
\text { Terbukti/Diterima }\end{array}$ \\
\hline
\end{tabular}

Sumber : Data Diolah, 2014

Berdasarkan hasil pengujian hipotesis pada tabel 6 tampak bahwa hipotesis penelitian yakni, kinerja keuangan daerah berpengaruh positif terhadap belanja modal untuk pelayanan publik dapat terdukung dan diterima, dimana nilai beta +1.753 dan nilai p_value $<\alpha=0,10$ atau $(0,060<\alpha=0,10)$. 


\subsection{Pembahasan}

Belanja modal jenis pelayanan publik adalah belanja yang digunakan untuk membiayai kegiatan investasi (menambah aset) yang ditujukan untuk peningkatan sarana dan prasarana publik yang hasilnya dapat digunakan langsung oleh masyarakat. Belanja modal jenis ini terdiri atas belanja tanah, belanja modal jalan dan jembatan, belanja modal bangunan air (irigasi), belanja modal instalasi, belanja modal jaringan, belanja modal bangunan gedung untuk kegiatan kemasyarakatan, belanja modal monumen, belanja modal alat-alat angkutan, alat-alat bengkel, alat-alat alat-alat kedokteran, alat-alat laboratorium, belanja modal buku/perpustakaan, barang bercorak kesenian dan budaya, belanja modal hewan ternak serta tanaman, belanja modal alat-alat persenjataan/keamanan.

Berdasarkan hasil pengujian hipotesis dengan menggunakan uji t_statistik pada tingkat kepercayaan $90 \%$ atau $(\alpha=0,10)$ diperoleh bukti empiris bahwa kinerja keuangan daerah berpengaruh positif terhadap belanja modal untuk pelayanan publik pada pemerintah Kabupaten/Kota se-Sumatera.

\section{Kesimpulan, Saran dan Keterbatasan}

\subsection{Kesimpulan}

Penelitian ini bertujuan untuk memberikan bukti empiris pengaruh kinerja keuangan daerah terhadap belanja modal untuk pelayanan publik pada pemerintah Kabupaten/Kota seSumatera. Berdasarkan hasil penelitian dan pembahasan dapat disimpulkan bahwa kinerja keuangan daerah berpengaruh positif terhadap belanja modal untuk pelayanan publik pada pemerintah Kabupaten/Kota se-Sumatera. Hal ini dikarenakan belanja modal untuk pelayanan publik membutuhkan dana yang besar, dan hanya pemerintah daerah yang kinerja keuangannya baik yang sanggup dan mampu untuk merealisasikannya.

\subsection{Saran}

Berdasarkan kesimpulan penelitian, maka salah satu solusi untuk dapat meningkatkan belanja modal pelayanan publik pada pemerintah daerah Kabupaten/Kota se-Sumatera dalam rangka meningkatkan pelayanan dan kesejahteraan masyarakat dapat dilakukan melalui perbaikan dan peningkatan kinerja keuangan pemerintah daerah melalui implementasi dan pengawasan yang baik terhadap peraturan-peraturan yang ada tentang PAD dan juga belanja daerah. Tanpa peningkatan kinerja keuangan, pemerintah daerah akan mengalami kesulitan 
untuk meningkatkan pelayanan dan kesejahteraan masyarakat melalui belanja modal untuk pelayanan publik.

\subsection{Keterbatasan}

Adapun keterbatasan penelitian ini sebagai berikut:

1. Objek penelitian terbatas hanya pada pemerintah Kabupaten/Kota se-Sumatera, sehingga hasilnya tidak dapat digeneralisasi.

2. Pengukuran kinerja kinerja keuangan daerah yang digunakan terbatas hanya pada rasio kemandirian keuangan, rasio efektifitas keuangan, dan rasio efisiensi keuangan. Sehingga hasil penelitian juga terbatas hanya pada rasio-rasio tersebut

\section{Daftar Pustaka}

Ardhini. 2011. Pengaruh Rasio Keuangan Daerah terhadap Belanja Modal untuk Pelayanan Publik dalam Perspektif Teori Keagenan. UNDIP. Skripsi

Badan Pemeriksa Keuangan Republik Indonesia. 2009. Laporan Hasil Pemeriksaan atas Laporan Keuangan Pemerintah Daerah Tahun Anggaran 2008

Budiarto, Bambang. 2007. Pengukuran Keberhasilan Pengelolaan Keuangan Daerah. Seminar Ekonomi Daerah. Surabaya.

Dwirandra, A.A.N.B. 2006. Efektivitas dan Kemandirian Keuangan Daerah Otonom Kabupaten/Kota di Provinsi Bali Tahun 2002 - 2006. Simposium Nasional Akuntansi X.

Ghazali, Imam. 2006. Aplikasi Analisis Multivariate dengan SPSS. Semarang. BP_Universitas Diponegoro.

Halim, Abdul \& Syukriy Abdullah. 2009. Hubungan dan masalah keagenan di pemerintahan daerah: sebuah peluang penelitian anggaran dan akuntansi. Jurnal Akuntansi Pemerintah 2(1): 53-64.

2003. Pengaruh Dana Alokasi Umum (DAU) dan Pendapatan Asli Daerah (PAD) Terhadap Belanja Pemerintah Daerah: Studi Kasus Kabupaten/Kota di Jawa dan Bali. Simposium Nasional Akuntansi VI, 1140-1159

Halim, Abdul. 2002. Bunga Rampai Manajemen Keuangan Daerah. Edisi Revisi. Yogyakarta. UPP AMP YKPN.

Hamzah, Ardi 2006, Pengaruh Belanja dan Pendapatan terhadap pertumbuhan Ekonomi, Kemiskinan dan Pengangguran. Jatim. Konferensi Penelitian. 
Handayani, Sri. 2011. Akuntansi Sektor Publik: Pendekatan Penganggaran Daerah dan Akuntansi Keuangan Daerah. Penerbit UNDIP: Semarang.

Hariadi, Priyo, Harianto, David, 2007. Hubungan Belanja Modal, DAU, PAD,dan Pendapatan Perkapita pada Kabupatan se-Jawa Bali. Simposium Nasional Akuntansi X. Makasar.

Haryanto, Joko Tri. 2005. Analisa Data Alokasi Umum (DAU) Kaitannya Dengan Penciptaan Kemandirian Daerah di Era Otonomi: Studi Kasus 30 Propinsi di Indonesia. Simposium Riset Ekonomi II. Surabaya.

Hirawan, Susiati B, 1990, "Keleluasaan daerah atau kontrol pusat?", dalam Arsyad Anwar dan Iwan Jaya Azis (Editor), Bunga Rampai Ekonomi, FE UI, Jakarta. 